\title{
Pyrimidinone conjugates for the assignment of the absolute configuration of $\alpha$-chiral carboxylic acids by ${ }^{1} \mathrm{H}-\mathrm{NMR}$
}

\author{
Robert S. Murray, ${ }^{1 \mathrm{a}}$ Vincent A. Boyd, ${ }^{2 \mathrm{a}}$ Vincent M. Lynch, ${ }^{\mathrm{b}}$ and George R. Negrete ${ }^{\mathrm{a} *}$ \\ ${ }^{a}$ Department of Chemistry, University of Texas at San Antonio, San Antonio, TX 78249 \\ ${ }^{b}$ Department of Chemistry and Biochemistry, The University of Texas at Austin, Austin, TX \\ 78712 \\ E-mail:gnegrete@utsa.edu
}

(received 04 Dec 01; accepted 14 Mar 02; published on the web 22 Mar 02)

\begin{abstract}
A method is described for the assignment of the absolute configuration of carboxylic acids via the formation of diastereomeric conjugates with known chiral dihydropyrimidinone 1. Proton NMR $\Delta \delta(R-S)$ values of conjugates with low molecular weight aromatic and aliphatic carboxylic acids with chiral centers in the alpha position were examined. The signals of primary interest corresponded to the dihydropyrimidinone. Several clearly resolved signals were exhibited at disparate locations of the spectrum with the magnitude and sign of $\Delta \delta(R-S)$ separation dependent upon acid structure.
\end{abstract}

Keywords: Chiral derivatizing agent, absolute configuration assignment, arylacetic acid, dihydropyrimidinone, chiral carboxylic acid

\section{Introduction}

The importance of chiral carboxylic acids in natural products and therapeutic agents spurs the continued development of highly selective methods for their preparation and stereochemical analysis. Though several methods for asymmetric carboxylic acid preparations are highly reliable in effecting predictable stereochemical outcomes, each synthesis requires an independent confirmation of the product configuration and purity. Proton NMR, in particular, has been widely employed to provide dependable assignments for carboxylic acids, ${ }^{3-7}$ alcohols, ${ }^{8,9}$ and amines ${ }^{10-14}$ covalently bound to chiral derivatizing agents (CDAs). In this report we describe the determination of the absolute configuration of chiral acids via proton NMR analysis of their conjugates with known dihydropyrimidinone $1 .{ }^{15}$ 


\section{Results and Discussion}

We recently reported that novel dihydropyrimidinones $\mathbf{2}$ and $\mathbf{3}$ imparted enhanced chirality transfer compared to $\mathbf{1}$ as chiral auxiliaries in enolate alkylations. ${ }^{16}$ Enolate methylations of the phenylacetate analogs of these heterocycles generated diastereomeric products $\mathbf{A}$ (the major product) and $\mathbf{B}$. The proton NMR chemical shifts from each diastereomeric pair produced $\Delta \delta(R-$ $S$ ) values consistent in sign (Table 1). For example, the $\mathrm{C} 5-H$ yielded negative $\Delta \delta(R-S)$ values for all derivatives, as did each of the other non-aryl protons from the diastereomeric products. We recognized that these chemical shift patterns form a potential basis for absolute configuration assignments of carboxylic acids and that the present system incorporated several advantages over other reported chiral derivatizing agents. First, as clearly indicated in Table 1, the proton NMR signals span a wide spectral range permitting assignments from several independent regions. Second, the assignments are facilitated by significant signal separations and splitting simplicities. Third, the tert-butyl singlets of analogs of $\mathbf{1}$, in particular, enable the examination of highly dilute samples. Here we describe investigations on aspects of the generality of this approach with respect to carboxylic acid structure.

Table 1. Proton NMR shift and $\Delta \delta . R-S)$ values of the diastereomeric products in $\left(\mathrm{CDCl}_{3}, 300\right.$ MHz). $\Delta \delta=\delta \mathrm{A}-\delta$ B corresponding to $\delta 2^{\prime} R, 2 R-\delta 2^{\prime} S, 2 R$

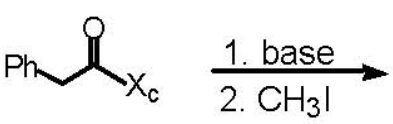

phenylacetate

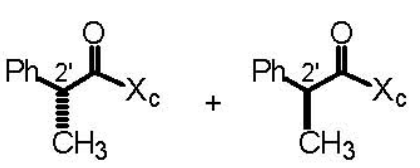

A $(2$ 'R)

$\mathrm{B}(2 \mathrm{~S})$

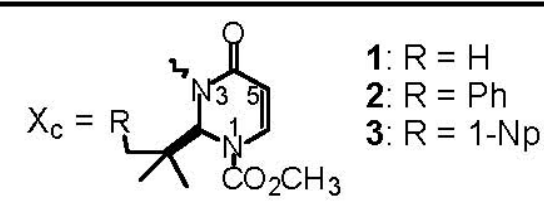

\begin{tabular}{cccc}
\hline Proton & $\delta 1 \mathrm{~A} / \delta 1 \mathrm{~B}(\Delta \delta)$ & $\delta 2 \mathrm{~A} / \delta 2 \mathrm{~B}(\Delta \delta)$ & $\delta 3 \mathrm{~A} / \delta 3 \mathrm{~B}(\Delta \delta)$ \\
\hline $\mathrm{C}\left(\mathrm{CH}_{3}\right)_{2} \mathrm{CH}_{2}-\mathrm{R}$ & $0.96 / 0.80(+0.16)$ & $0.66 / 0.82(+0.16)$ & $0.62 / 0.83(+0.21)$ \\
$\mathrm{C}^{\prime} \mathrm{H}_{3}$ & $1.52 / 1.45(+0.07)$ & $1.54 / 1.48(+0.06)$ & $1.57 / 1.51(+0.06)$ \\
$\mathrm{CO}_{2} \mathrm{CH}_{3}$ & $3.83 / 3.89(-0.06)$ & $3.86 / 3.90(-0.04)$ & $3.88 / 3.94(-0.06)$ \\
$\mathrm{C}^{\prime}-\mathrm{H}$ & $4.97 / 4.80(+0.17)$ & $4.99 / 4.87(+0.12)$ & $5.03 / 4.89(+0.14)$ \\
$\mathrm{C} 5-\mathrm{H}$ & $5.13 / 5.33(-0.20)$ & $5.18 / 5.39(-0.21)$ & $5.21 / 5.42(-0.21)$ \\
$\mathrm{C} 2-\mathrm{H}$ & $6.69 / 6.92(-0.23)$ & $6.84 / 7.09(-0.25)$ & $7.00 / 7.25(-0.25)$ \\
$\mathrm{C} 6-\mathrm{H}$ & $7.46 / 7.65(-0.19)$ & $7.53 / 7.71(-0.18)$ & $7.55 / 7.72(-0.17)$ \\
\hline
\end{tabular}

A series of diastereomeric conjugates of $\mathbf{1}$ were prepared to examine the effect of carboxylic acid structure on the proton NMR shifts patterns (Table 2). The analogs were designed to examine the influence of the size of the alkyl group (4 and 5), the presence of a heteroatom attached to the chiral center (6), and the size of the aryl group (7 and 8) or its absence (12-14). In addition, other samples were prepared to investigate combinations of structural influences (9) or commercially important applications (10 and $\mathbf{1 1})$. 
Several strategies were employed to generate the targeted samples for these studies. Compounds 4-, 6-, 10- and 12AB were prepared as diastereomerically enriched samples from the commercially available, chiral carboxylic acids. Typically, coupling of the carboxylic acid to the heterocycle was accomplished by formation of the acid chloride and subsequent exposure to the metallated heterocycle, although it was also found that $\mathbf{1}$ could be directly attached to the carboxylic acid without epimerization ${ }^{17}$ upon exposure to DCC/DMAP. Diastereomeric pairs of several analogs $(5,7$, and 9) required the preparation of the corresponding chiral acids followed by coupling as described. In these samples, the commercially available arylacetic acids were converted to the methyl esters and each enolate was alkylated with iodomethane or 2iodopropane as appropriate. Subsequent saponification and resolution with $(R)-\alpha$ methylbenzylamine generated optically enriched materials that were appended to $\mathbf{1}$ as described. Diastereomers 8AB were prepared via coupling of the commercially available 1-pyreneacetic acid to $\mathbf{1}$ and the product was alkylated as the enolate. The absolute configurations of the major products of the latter reaction were assigned according to the known chirality transfer property of this system. ${ }^{15}$ Conjugate 11B was prepared via coupling of commercially available $(S)$-Naproxen with 1. The sample was epimerized under basic conditions to generate the corresponding diastereomer 11A.

Table 2. Selected ${ }^{1} \mathrm{H}$ NMR (ppm) and $\left.\Delta \delta R-S\right)$ values of 4-14 (300 MHz, acetone- $\left.d_{6}\right)$

\begin{tabular}{|c|c|c|c|c|c|c|c|c|c|c|}
\hline Sample & $\mathrm{R}$ & $\mathrm{R}^{1}$ & $\left(\mathrm{C}-\mathrm{H}_{3}\right)_{3}$ & $\Delta \delta$ & $\mathrm{C} 5-\mathrm{H}$ & $\Delta \delta$ & $\begin{array}{c}\mathrm{C} 2- \\
\mathrm{H}\end{array}$ & $\Delta \delta$ & C6-H & $\Delta \delta$ \\
\hline $4 \mathrm{~A}$ & Et & $\mathrm{Ph}$ & 0.97 & \multirow{2}{*}{+0.07} & 5.15 & \multirow{2}{*}{-0.20} & 6.74 & \multirow{2}{*}{-0.18} & 7.58 & \multirow{2}{*}{-0.20} \\
\hline $4 B$ & Et & $\mathrm{Ph}$ & 0.90 & & 5.35 & & 6.92 & & 7.78 & \\
\hline $5 A$ & iPr & $\mathrm{Ph}$ & 0.96 & \multirow{2}{*}{+0.19} & 5.19 & \multirow{2}{*}{-0.19} & 6.72 & \multirow{2}{*}{-0.18} & 7.57 & \multirow{2}{*}{-0.24} \\
\hline 5B & iPr & $\mathrm{Ph}$ & 0.77 & & 5.38 & & 6.90 & & 7.81 & \\
\hline $6 \mathrm{~A}$ & $\mathrm{OMe}$ & $\mathrm{Ph}$ & 0.97 & \multirow{2}{*}{+0.20} & 5.12 & \multirow{2}{*}{-0.23} & 6.69 & \multirow{2}{*}{-0.17} & 7.48 & \multirow{2}{*}{-0.21} \\
\hline $6 B$ & $\mathrm{OMe}$ & $\mathrm{Ph}$ & 0.77 & & 5.35 & & 6.86 & & 7.69 & \\
\hline $7 \mathrm{~A}$ & $\mathrm{Me}$ & 1-naphthyl & 0.97 & \multirow{2}{*}{+0.07} & 4.91 & \multirow{2}{*}{-0.41} & 6.76 & \multirow{2}{*}{-0.20} & 7.52 & \multirow{2}{*}{-0.28} \\
\hline 7B & $\mathrm{Me}$ & 1-naphthyl & 0.90 & & 5.32 & & 6.96 & & 7.80 & \\
\hline $\mathbf{8 A}$ & $\mathrm{Me}$ & 1-pyrenyl & 0.98 & \multirow{2}{*}{+0.09} & 4.71 & \multirow{2}{*}{-0.61} & 6.80 & \multirow{2}{*}{-0.23} & 7.35 & \multirow{2}{*}{-0.46} \\
\hline 8B & $\mathrm{Me}$ & 1-pyrenyl & 0.89 & & 5.32 & & 7.03 & & 7.81 & \\
\hline 9A & $\mathrm{iPr}$ & 1-naphthyl & 0.94 & \multirow{2}{*}{+0.11} & 4.95 & \multirow{2}{*}{-0.40} & 6.64 & \multirow{2}{*}{-0.33} & 8.10 & \multirow{2}{*}{-0.37} \\
\hline 9B & iPr & 1-naphthyl & 0.73 & & 5.35 & & 6.97 & & 8.47 & \\
\hline $10 A$ & $\mathrm{Me}$ & $\mathrm{p}-\mathrm{iBu}-\mathrm{C}_{6} \mathrm{H}_{4}$ & 0.94 & \multirow{2}{*}{+0.16} & 5.11 & \multirow{2}{*}{-0.22} & 6.67 & \multirow{2}{*}{-0.26} & 7.55 & \multirow{2}{*}{-0.21} \\
\hline 10B & $\mathrm{Me}$ & p-iBu- $\mathrm{C}_{6} \mathrm{H}_{4}$ & 0.78 & & 5.33 & & 6.93 & & 7.76 & \\
\hline
\end{tabular}


Table 2. Continued

\begin{tabular}{|c|c|c|c|c|c|c|c|c|c|c|}
\hline $11 \mathrm{~A}$ & $\mathrm{Me}$ & $\mathrm{Ar}^{\mathrm{a}}$ & 0.94 & \multirow{2}{*}{+0.16} & 5.14 & \multirow{2}{*}{-0.20} & $\mathrm{nr}^{\mathrm{b}}$ & \multirow{2}{*}{-} & 7.46 & \multirow{2}{*}{-0.10} \\
\hline 11B & $\mathrm{Me}$ & $\mathrm{Ar}^{\mathrm{a}}$ & 0.78 & & 5.34 & & $\mathrm{nr}^{\mathrm{b}}$ & & 7.56 & \\
\hline $12 \mathrm{~A}$ & $\mathrm{Me}$ & Et & 0.93 & \multirow{2}{*}{0} & 5.35 & \multirow{2}{*}{+0.02} & 6.84 & \multirow{2}{*}{-0.04} & 7.78 & \multirow{2}{*}{+0.02} \\
\hline 12B & $\mathrm{Me}$ & Et & 0.93 & & 5.33 & & 6.88 & & 7.76 & \\
\hline $13 A$ & $\mathrm{Me}$ & iPr & 0.94 & \multirow{2}{*}{0} & 5.37 & \multirow{2}{*}{+0.06} & 6.79 & \multirow{2}{*}{-0.11} & 7.81 & \multirow{2}{*}{+0.06} \\
\hline 13B & $\mathrm{Me}$ & iPr & 0.94 & & 5.31 & & 6.90 & & 7.75 & \\
\hline $14 \mathrm{~A}$ & $\mathrm{Me}$ & $\mathrm{C}_{6} \mathrm{H}_{11}$ & 0.94 & \multirow{2}{*}{0} & 5.36 & \multirow{2}{*}{+0.03} & 6.78 & \multirow{2}{*}{-0.11} & 7.80 & \multirow{2}{*}{+0.04} \\
\hline 14B & $\mathrm{Me}$ & $\mathrm{C}_{6} \mathrm{H}_{11}$ & 0.94 & & 5.33 & & 6.89 & & 7.76 & \\
\hline
\end{tabular}

${ }^{\mathrm{a}} \mathrm{Ar}=2$-(6-methoxynaphthyl); ${ }^{\mathrm{b}}$ data obscured by overlapping signals.

Preparation of the dialkylacetic acid precursors for diastereomers $13 \mathrm{AB}$ and $14 \mathrm{AB}$ required additional manipulations due to the volatility of the respective methyl esters. The carboxylic acids for 13AB were prepared by conversion of 3-methylbutyric acid to the corresponding acid chloride followed by coupling to 2-oxazolidinone. Subsequent enolate alkylation, base catalysed hydrolysis, and coupling to $\mathbf{1}$ generated the diastereomeric products. After chromatographic separation, the relative configurations of these diastereomers were assigned based on spectroscopic identity with the major and minor products obtained for the enolate alkylation of the propionyl analog of 1 with 2-iodopropane. Diastereomers $\mathbf{1 4 A B}$ were analogously prepared from cyclohexylacetic acid.

The diastereomeric samples prepared as described above were enriched by normal phase chromatography (5-20\% ethyl acetate in hexanes). In each case, the more mobile isomer was identified as the $2^{\prime} R$ isomer (A), though, for $\mathbf{5 A B}$, three chromatographic cycles were required for adequate sample enrichment. While the consistency of the elution trends may also permit the relative stereochemical assignments for these compounds, ${ }^{3}$ no assignments were made on the basis of these phenomena.

Spectroscopic samples were prepared (approximately $0.03 \mathrm{mM}$ in acetone- $d_{6}$ or $\mathrm{CDCl}_{3}$ ) from the enriched samples, and for all diastereomeric pairs, a mixed sample was prepared and examined to confirm the chemical shift differences recorded from the spectra of highly enriched diastereomers (Table 2). The chemical shifts and coupling magnitudes for $\mathrm{C} 2-\mathrm{H}, \mathrm{C} 5-\mathrm{H}$, and C6$\mathrm{H}$ in $\mathrm{CDCl}_{3}$ for most samples were exhibited as highly broadened singlets that complicated signal assignments. Fortunately, these difficulties were ameliorated in acetone- $d_{6}$ (see Figure 1). For example, the C6- $H$ signals for $\mathbf{5 A}$ and $\mathbf{5 B}$ were difficult to identify or correlate to the appropriate proton in $\mathrm{CDCl}_{3}$. However, the signals were exhibited with the expected multiplicities, including $w$-couplings in most cases, facilitating spectral assignments. Gratifyingly, the use of acetone- $d_{6}$ did not modify the relative location or magnitude of $\Delta \delta(R-S)$ for any of the signals described above. Thus, acetone- $d_{6}$ is the preferred solvent for these studies, though $\mathrm{CDCl}_{3}$ may be employed in situations where protons other than $\mathrm{C} 2-\mathrm{H}, \mathrm{C} 5-\mathrm{H}$, and $\mathrm{C} 6-\mathrm{H}$ protons are observed. 


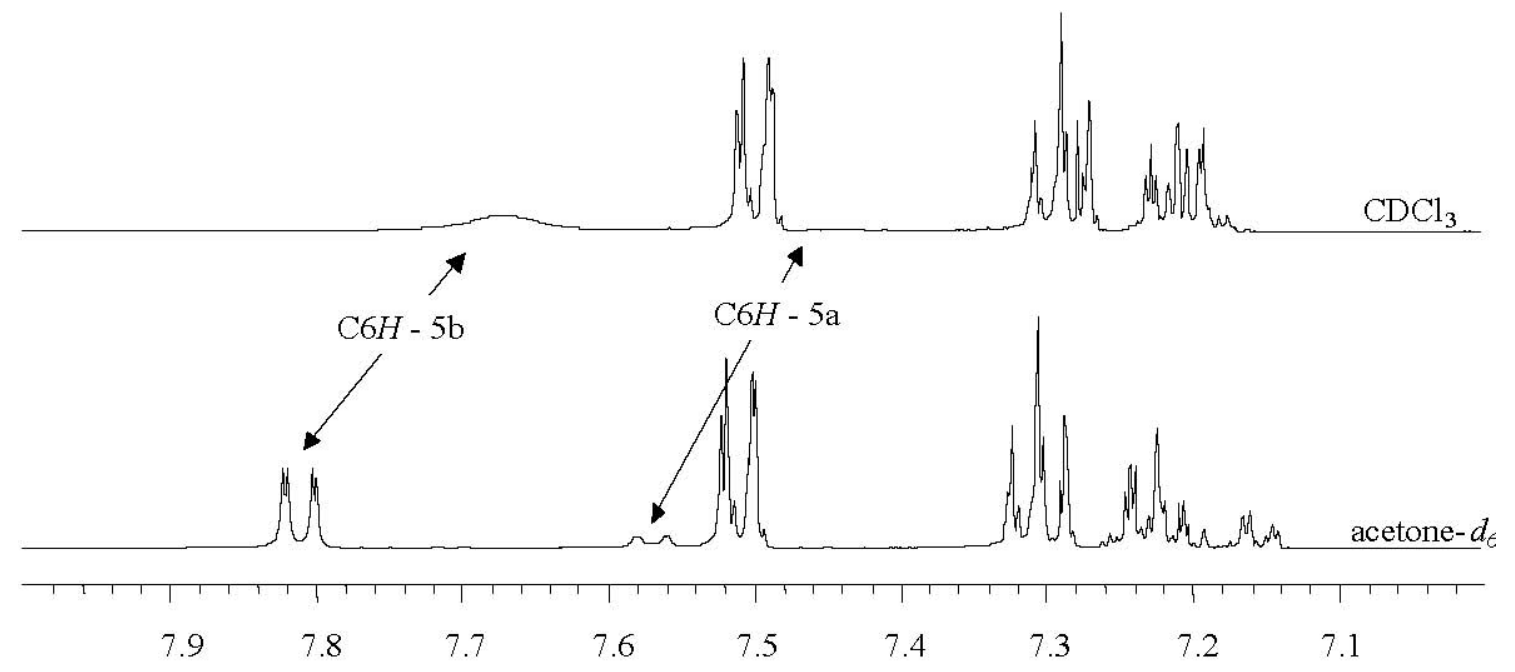

Figure 1. ${ }^{1} \mathrm{H}$ NMR spectra of the $C 6-H$ and aromatic regions of $\mathbf{5 A B}(\mathbf{5 B}$ is in excess of $\mathbf{5 A})$ in $\mathrm{CDCl}_{3}$ (top) and in acetone- $d_{6}$ (bottom).

Proton NMR analyses of 2'-arylcarboxylic acid analogs 4-10 revealed a pattern of chemical shift differences that were identical to those previously observed for 1-3. For example, each diastereomer A exhibited an upfield shift for $\mathrm{C} 5-\mathrm{H}$ and $\mathrm{C} 6-\mathrm{H}$ of $0.2 \mathrm{ppm}$ (or larger) relative to $\mathbf{B}$. The increased separation of the $\mathrm{C} 5-H$ signals for larger aryl groups (e.g. 0.41 and $0.61 \mathrm{ppm}$ for 1-naphthyl and 1-pyrenyl, respectively) suggests that the differences arise from ring current effects caused by the aryl moiety. Similar patterns of chemical shift differences were also reproduced for the remaining protons (Table 3). In addition, the trends were followed by the conjugates of 2-alkoxy-2-phenylacids 6, 3-methyl-2-(1-naphthyl)butyric acids 9, ${ }^{19}$ Ibuprofen (10), and Naproxen (11).

Proton NMR analyses of dialkylacetic acid derivatives 10-12 produced significantly smaller $\Delta \delta(R-S)$ separations, and for all but the $\mathrm{C} 2-H$ proton, were opposite in sign compared with derivatives containing an aryl group. The chemical shift differences observed for the latter proton may originate from the nearby $\mathrm{Cl}^{\prime}$-carbonyl anisotropy or other structural difference between the diastereomers. Conversely $\mathrm{C} 5-\mathrm{H}, \mathrm{C} 6-\mathrm{H}$, and the tert-butyl protons exhibited significantly reduced, or reversed, positioning of the corresponding chemical shifts relative to the $2^{\prime}$ arylcarboxylic acids. For example, the $\mathrm{C} 5-\mathrm{H}$ signal of 10A was downfield of the corresponding proton for 10B $(+0.03 \mathrm{ppm})$. These results provide additional support for the suggestion that the aryl group anisotropy impacts the position of the aforementioned four NMR signals. 
Table 3. $\Delta \delta(R-S)$ values of $\mathbf{4 a b}-\mathbf{1 4 a b}$ recorded in acetone- $d_{6}(\mathrm{ad})$ and $\mathrm{CDCl}_{3}(\mathrm{~cd})$ at $300 \mathrm{MHz}$

\begin{tabular}{|c|c|c|c|c|c|c|c|c|c|c|c|c|c|c|}
\hline \multirow[b]{2}{*}{ Cpd } & \multicolumn{2}{|c|}{$\mathrm{C} 2 \mathrm{H}$} & \multicolumn{2}{|c|}{$\mathrm{C} 5 \mathrm{H}$} & \multicolumn{2}{|c|}{$\mathrm{C} 6 \mathrm{H}$} & \multicolumn{2}{|c|}{ 7-H } & \multicolumn{2}{|c|}{ 8-H } & \multicolumn{2}{|c|}{$\mathrm{C} 2{ }^{\prime} \mathrm{H}$} & \multicolumn{2}{|c|}{ C3'H } \\
\hline & $\mathrm{Ad}$ & $\mathrm{cd}$ & $\mathrm{ad}$ & $\mathrm{cd}$ & $\mathrm{ad}$ & $\mathrm{cd}$ & $\mathrm{ad}$ & $\mathrm{cd}$ & $\mathrm{ad}$ & $\mathrm{cd}$ & $\mathrm{ad}$ & $\mathrm{cd}$ & $\mathrm{ad}$ & $\mathrm{cd}$ \\
\hline $4 \mathbf{a b}$ & - & - & - & - & - & - & - & - & + & + & + & + & + & + \\
\hline $5 \mathbf{a b}$ & - & - & - & - & - & - & - & - & + & + & + & + & + & + \\
\hline 6ab & - & - & - & - & - & - & - & - & + & + & + & + & & \\
\hline $7 \mathbf{a b}$ & - & - & - & - & - & $\mathrm{nr}$ & - & - & + & + & + & + & + & + \\
\hline $8 \mathbf{a b}$ & - & - & - & - & - & - & - & - & + & + & + & + & + & + \\
\hline 9ab & - & - & - & - & - & $\mathrm{nr}$ & - & - & + & + & + & + & + & + \\
\hline 10ab & - & - & - & - & - & - & - & - & + & + & + & + & + & + \\
\hline 11ab & $\mathrm{nr}$ & ne & - & ne & - & ne & - & ne & + & ne & + & ne & + & ne \\
\hline 12ab & - & - & + & + & + & 0 & + & 0 & 0 & 0 & - & - & + & + \\
\hline 13ab & - & - & + & + & + & 0 & + & 0 & 0 & 0 & - & - & + & + \\
\hline $14 \mathrm{ab}$ & - & - & + & + & + & 0 & + & 0 & 0 & 0 & - & - & + & + \\
\hline
\end{tabular}

$*$ nr $=$ not resolved, ne $=$ not examined.

An X-ray analysis was performed on 9B. The requisite acid, (S)-3-methyl-2-(1naphthyl)butyric acid, was prepared via enolate alkylation of the methyl ester of 1-naphthylacetic acid with 2 -iodopropane followed by resolution with $(S)$ - $\alpha$-methylbenzylamine. The resolved acid, which was previously prepared and assigned the $S$ configuration by Piccolo, ${ }^{19}$ was coupled with 1. Enriched diastereomer 9B was similarly obtained via coupling of $\mathbf{1}$ to the acid recovered from the mother liquor of the acid prepared for the synthesis of $\mathbf{9 A}$. Based on the proton NMR data presented for the arylacetic acid samples (4-8, 10, and 11), the acid derived from the crystalline salt was assigned the $S$ configuration (9B), consistent with the reported assignment. The relative configurations of the stereocenters of crystalline 9B were confirmed by X-ray analysis (see Figure 2), thus enabling an unambiguous assignment of the $(S)-\mathrm{C} 2$ ' configuration based on known $1 .^{15}$ The structure exhibits anti imide carbonyls with the naphthyl and tert-butyl groups in close proximity suggesting that aryl anisotropy influences the chemical shift of the tert-butyl group. The structural origin of the remainder of the chemical shift differences cannot readily be inferred from the X-ray data.

Overall, these data strongly support the generality of proton NMR-derived configurational assignments for pyrimidinone analogs of 2-alkyl-2-aryl- and 2-alkoxy-2-arylcarboxylic acids. In addition, dialkylacetic acid derivatives may be determined based on the sign of the $\mathrm{C} 2-H \Delta \delta .(R-$ $S)$ value, though, additional investigations are necessary to examine the consistency of the trend. Studies are ongoing to elucidate the structural properties underlying the spectroscopic differences described here and to examine other trends in the spectral and chromatographic properties of the diastereomeric conjugates of $\mathbf{1}$. 


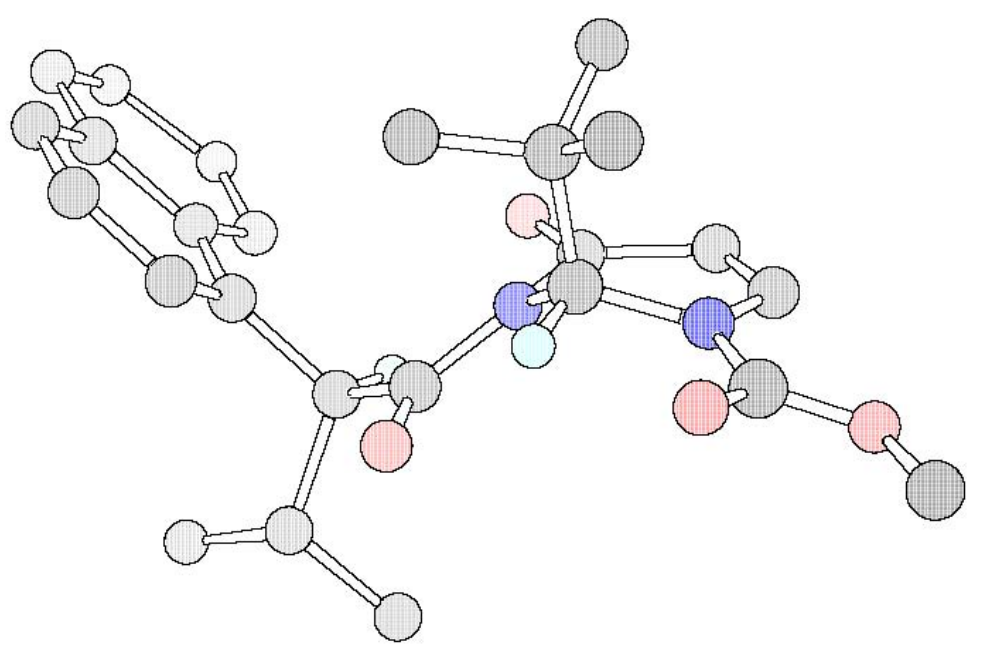

Figure 2. View of 9B displayed on CHEM $3 \mathrm{D}^{\circledR}$ using coordinates from X-ray crystallography. Most hydrogen atoms are removed for clarity.

\section{Experimental Section}

General Procedures. Proton ( ${ }^{1} \mathrm{H}$ NMR) and carbon-13 $\left({ }^{13} \mathrm{C}\right.$ NMR $)$ magnetic resonance spectra were recorded at $300 \mathrm{MHz}$ and $75 \mathrm{MHz}$ respectively in acetone- $d_{6}$ or $\mathrm{CDCl}_{3}$ at $25{ }^{\circ} \mathrm{C}$. Chemical shift values are reported in ppm with TMS as an internal reference. $J$ values are given in $\mathrm{Hz}$. COSY spectroscopy was used to identify overlapping proton signals where appropriate. Optical rotation was recorded on a JASCO DIP-1000 digital polarimeter. Kieselgel $60 \mathrm{~F}_{254}$ silica gel TLC plates were used for monitoring reaction progress. Flash chromatography was performed using silica gel (Aldrich, 200-300 mesh) with ethyl acetate-hexanes gradients. Reactions were routinely effected under a dry nitrogen atmosphere with magnetic stirring.

Materials. Tetrahydrofuran (THF) was distilled from sodium metal with benzophenone, and dichloromethane (DCM) from $\mathrm{CaH}$ immediately prior to use. Sodium hexamethyldisilazide (NaHMDS) and lithium hexamethyldisilazide (LiHMDS) were purchased from Aldrich Chemical Company and titrated prior to use with diphenylacetic acid. ( \pm )-2-Phenylpropionic acid, $(R)$-2-phenylpropionic acid, $( \pm)$-2-phenylbutanoic acid, $(R)$-2-phenylpropionic acid, $( \pm)$-2(4-nitrophenyl)propionic acid, $( \pm)-(O)$-methylmandelic acid, $(R)-(O)$-methylmandelic acid, $( \pm)-$ 2-methylbutanoyl chloride, (R)-2-methylbutanoyl chloride, and (S)-2-[2-(6-methoxynapthyl)]propionic acid were purchased from the Sigma-Aldrich Chemical Company.

(S)-2-tert-Butyl-1-carbomethoxy-2,3-dihydro-4(1H)-pyrimidinone (1). The title compound was prepared following the method of Konopelski ${ }^{15}$ in yields ranging from $30 \%$ to $55 \%$ from asparagine. ${ }^{1} \mathrm{H}$ NMR and ${ }^{13} \mathrm{C}$ NMR data were identical to the published data.

General method for the preparation of chiral 2-aryl carboxylic acids via ester enolate alkylation. The appropriate arylacetic acid was dissolved in methanol (5 $\mathrm{mL}$ per $\mathrm{mmol}$ acid), 
catalytic sulfuric acid was added, and the reaction was stirred and heated at $60{ }^{\circ} \mathrm{C}$. Upon complete esterification as determined by TLC, the reaction was concentrated to $1 / 5$ volume, diluted with ethyl acetate, and washed with a saturated sodium bicarbonate solution then brine. The organic layer was dried over $\mathrm{MgSO}_{4}$, filtered, and concentrated under reduced pressure. The resulting methyl ester was dissolved in THF and added dropwise to a cooled $\left(-46^{\circ} \mathrm{C}\right)$ solution of LiHMDS (1.0 equiv., 1.0 M in THF) and HMPA (1.0 equiv.) diluted to $0.02 \mathrm{M}$ in THF. The cooled reaction was stirred for an additional $1 \mathrm{~h}$. An appropriate alkyl iodide (2 equiv.) was added and the reaction was stirred for $1 \mathrm{~h}$ at $-46{ }^{\circ} \mathrm{C}$ then allowed to gradually warm to room temperature with stirring until judged complete by TLC. The reaction was quenched with saturated ammonium chloride, diluted with ethyl acetate, and washed sequentially with saturated ammonium chloride then brine. Evaporation of solvent under reduced pressure left behind mixtures of alkylated and non-alkylated esters. Reaction mixtures with poor conversion to the desired alkylated ester were separated by flash chromatography (5-10\% ethyl acetate in hexanes) prior to hydrolysis as described below. Reaction mixtures with complete or nearly complete alkylation were hydrolyzed (10 equiv. $\mathrm{NaOH}, 1: 1 \mathrm{THF}-\mathrm{H}_{2} \mathrm{O}$, reflux) and extractively isolated. Crystallizations were attempted from the slow evaporation of ethyl acetate where applicable.

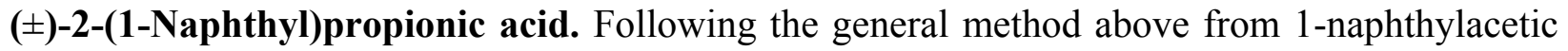
acid and methyl iodide, without purification as the methyl ester, $65 \%$ yield after crystallization, as colorless crystals. ${ }^{1} \mathrm{H}$ NMR $\left(\mathrm{CDCl}_{3}\right) \delta .1 .66(\mathrm{~d}, J=7.2,3 \mathrm{H}), 4.53(\mathrm{q}, J=7.2,1 \mathrm{H}), 7.41-8.10$ $(\mathrm{m}, 7 \mathrm{H})$ in agreement with the literature values. ${ }^{20}$

$( \pm)$-2-(1-Pyrenyl)propionic acid. Following the general method above from 1-pyrenylacetic acid and methyl iodide, with flash column purification (5-10\% ethyl acetate in hexanes) as the methyl ester, 35\% yield after hydrolysis, as a tan solid that darkened upon exposure to light. ${ }^{1} \mathrm{H}$ NMR $\left(\mathrm{CDCl}_{3}\right.$, methyl ester) $\delta 1.76(\mathrm{~d}, J=6.9,3 \mathrm{H}), 3.65(\mathrm{~s}, 3 \mathrm{H}), 4.80$ (q, $\left.J=7.2,1 \mathrm{H}\right), 7.96-8.12$ $(\mathrm{m}, 9 \mathrm{H}) ;{ }^{13} \mathrm{C}$ NMR (acetone- $d_{6}$, methyl ester) $\delta 19.4,42.2,52.4,123.8,125.9,125.9,126.1$, $126.3,126.4,127.2,127.2,128.3,128.5,128.5,128.9,131.5,131.9,132.5,136.5,175.8$.

$( \pm$ )-3-Methyl-2-phenylbutanoic acid. Following the general method above from phenylacetic acid and 2-iodopropane, after flash column purification of the methyl ester $(5 \%$ ethyl acetate in hexanes), 50\% yield as a colorless oil resisting crystallization. ${ }^{1} \mathrm{H}$ NMR $\left(\mathrm{CDCl}_{3}\right.$, methyl ester) $\delta 0.71(\mathrm{~d}, J=6.6,3 \mathrm{H}), 1.04(\mathrm{~d}, J=6.6,3 \mathrm{H}), 2.34(\mathrm{~m}, 1 \mathrm{H}), 3.15(\mathrm{~d}, J=10.5,1 \mathrm{H}), 3.62(\mathrm{~s}, 3 \mathrm{H})$, $7.32(\mathrm{~m}, 5 \mathrm{H})$ in agreement with the literature values. ${ }^{21}$

(R)-3-Methyl-2-phenylbutanoic acid. Following the protocol of Newman22 a solution of $( \pm)-3-$ methyl-2-phenylbutanoic acid (1.25 g, $7.0 \mathrm{mmol}),(R)-(+)-\alpha$-methylbenzylamine (850 $\mathrm{mg}$, $7.0 \mathrm{mmol})$, and $63 \%$ aqueous ethanol $(3.8 \mathrm{~mL})$ was warmed and allowed to cool slowly. The salts that separated were removed and recrystallized two additional times from $63 \%$ aqueous ethanol. The purified diastereomer salts were added to a cooled $\left(0{ }^{\circ} \mathrm{C}\right) 10 \%$ sulfuric acid solution and extracted twice with ethyl acetate. The combined organic layers were washed with brine, dried over $\mathrm{MgSO}_{4}$, filtered, and concentrated to an oil that upon standing solidified to give 
$274 \mathrm{mg}$ of a mixture predicted to be enriched with (R)-3-methyl-2-phenylbutanoic acid; $[\alpha]_{\mathrm{D} 25^{\circ}}\left(\mathrm{CHCl}_{3}, c 4.46\right)=-46.2($ lit.22 -62.4).

( \pm )-3-Methyl-2-(1-naphthyl)butanoic acid. Following the general method above from 1naphthylacetic acid and 2-iodopropane, after flash column purification of the methyl ester with $5 \%$ ethyl acetate in hexanes, $73 \%$ yield as a colorless oil that resisted crystallization; ${ }^{1} \mathrm{H}$ NMR $\left(\mathrm{CDCl}_{3}\right.$, methyl ester) $\delta 0.73(\mathrm{~d}, J=6.9,3 \mathrm{H}), 1.20(\mathrm{~d}, J=6.3,3 \mathrm{H}), 2.60(\mathrm{~m}, 1 \mathrm{H}), 3.63(\mathrm{~s}, 3 \mathrm{H})$, $4.15(\mathrm{~d}, J=10.2,1 \mathrm{H}), 7.46-8.26(\mathrm{~m}, 7 \mathrm{H})$.

(R)-3-Methyl-2-(1-naphthyl)butanoic acid. Following the protocol of Picollo ${ }^{19}$ a solution of ( \pm )-3-methyl-2-(1-naphthyl)butanoic acid (1.18 g, $5.17 \mathrm{mmol}),(R)-(+)-\alpha$-methylbenzylamine $(626 \mathrm{mg}, 5.17 \mathrm{mmol})$ and $50 \%$ aqueous ethanol $(13 \mathrm{~mL})$ was warmed and allowed to cool slowly. The separated salts were removed and recrystallized two additional times from 50\% aqueous ethanol. The purified diastereomer salts were added to a cooled $\left(0{ }^{\circ} \mathrm{C}\right) 10 \%$ sulfuric acid solution and extracted twice with ethyl acetate. The combined organic layers were washed with brine, dried over $\mathrm{MgSO}_{4}$, filtered, and concentrated to an oil that upon standing solidified to give $330 \mathrm{mg}$ of a mixture predicted to be enriched with $(R)$-3-methyl-2-naphthylbutanoic acid; ${ }^{1} \mathrm{H}$ NMR $\left(\mathrm{CDCl}_{3}\right.$, acid) $\delta 0.69(\mathrm{~d}, J=6.9,3 \mathrm{H}), 1.18(\mathrm{~d}, J=6.6,3 \mathrm{H}), 2.56(\mathrm{~m}, 1 \mathrm{H}), 4.08(\mathrm{~d}, J=$ $10.5,1 \mathrm{H}), 7.42-8.15(\mathrm{~m}, 7 \mathrm{H}) ;[\alpha]_{\mathrm{D}}{ }^{25^{\circ}}\left(\mathrm{PhH}, c^{2.363)}=-178.3\right.$ (lit. $\left.{ }^{19}-212.44\right)$.

( \pm )-2-(4-Isobutylphenyl)propionic acid. Two $200 \mathrm{mg}$ over-the-counter Ibuprofen tablets were pulverized in a mortar and pestle and dissolved in $200 \mathrm{~mL} 1 \mathrm{~N}$ aqueous $\mathrm{NaOH}$. The aqueous layer was washed 3 times with ethyl acetate then acidified to $\mathrm{pH}<2$ with sulfuric acid and extracted three times with ethyl acetate. The organic layers were combined, dried over $\mathrm{MgSO}_{4}$, filtered, and concentrated to an oil that solidified upon standing to give $420 \mathrm{mg}$ of a white solid. ${ }^{1} \mathrm{H}$ NMR $\left(\mathrm{CDCl}_{3}\right.$, acid) $\delta .0 .89(\mathrm{~d}, J=6.6,6 \mathrm{H}), 1.49(\mathrm{~d}, J=7.2,3 \mathrm{H}), 1.84(\mathrm{~m}, 1 \mathrm{H}), 2.44(\mathrm{~d}, J=$ $7.2,2 \mathrm{H}), 3.70(\mathrm{q}, J=6.9,1 \mathrm{H}), 7.22(\mathrm{~d}, J=7.8,2 \mathrm{H}), 7.10(\mathrm{~d}, J=8.1,2 \mathrm{H})$ in agreement with the literature values. $^{23}$

( \pm )-2,3-Dimethylbutanoic acid. 3-methylbutanoic acid (550 $\mathrm{mg}, 3.87 \mathrm{mmol})$ and DMF (305 mg, $3.87 \mathrm{mmol})$ were dissolved in DCM $(7.7 \mathrm{ml})$ and cooled to $0{ }^{\circ} \mathrm{C}$. Oxalyl chloride (982 mg, $7.74 \mathrm{mmol}$ ) was added and the solution was stirred at room temperature for $1 \mathrm{~h}$. The reaction was concentrated to $1 / 4$ volume, filtered rapidly to remove precipitated solids, and the filtrate stored under $\mathrm{N}_{2}$ for use in the proceeding step. In a separate reaction vessel, 2oxazolidinone $(337 \mathrm{mg}, 3.87 \mathrm{mmol})$ was dissolved in THF $(7.7 \mathrm{~mL})$ and cooled to $-46{ }^{\circ} \mathrm{C}$. NaHMDS (4.64 mL, $4.64 \mathrm{mmol}, 1 \mathrm{M}$ in THF) was added to the cooled reaction which was allowed to warm to room temperature for $10 \mathrm{~min}$ while stirring then cooled back to $-46{ }^{\circ} \mathrm{C}$. The acid chloride made previously was diluted to $0.5 \mathrm{~mL}$ with THF and added to the cooled oxazolidinone anion via cannula. The reaction was stirred $30 \mathrm{~min}$ at $-46^{\circ} \mathrm{C}$ then allowed to stir a further $1 \mathrm{~h}$ at $0{ }^{\circ} \mathrm{C}$. The reaction was quenched with saturated sodium bicarbonate, diluted with ethyl acetate and washed with brine. The organic layer was dried over $\mathrm{MgSO}_{4}$, filtered, and concentrated to an oil. Flash chromatography using 20\% ethyl acetate in hexanes hexanes provided $670 \mathrm{mg}$ 3-(3-methylbutanoic)-2-oxazolidinone (82\%) as a white solid; ${ }^{1} \mathrm{H}$ NMR $\left(\mathrm{CDCl}_{3}\right) \delta 0.97(\mathrm{~d}, J=6.6,6 \mathrm{H}), 2.17(\mathrm{~m}, 1 \mathrm{H}), 2.80(\mathrm{~d}, J=6.9,2 \mathrm{H}), 4.01(\mathrm{t}, J=8.1,2 \mathrm{H}), 4.39(\mathrm{t}$, 
$J=8.1,2 \mathrm{H}) ;{ }^{13} \mathrm{C} \mathrm{NMR}\left(\mathrm{CDCl}_{3}\right) \delta 22.4,24.9,42.5,43.5,61.9,153.5,172.8$. The acylated oxazolidinone $(660 \mathrm{mg}, 3.12 \mathrm{mmol})$ was dissolved in THF $(15 \mathrm{~mL})$ and cooled to $-46{ }^{\circ} \mathrm{C}$. NaHMDS (3.27 mL, $3.27 \mathrm{mmol}, 1.0 \mathrm{M}$ in THF) was added to the cooled solution that was stirred at this temperature for $1 \mathrm{~h}$. Methyl iodide $(885 \mathrm{mg}, 6.24 \mathrm{mmol})$ was added and the reaction was stirred $1 \mathrm{~h}$ at $-46{ }^{\circ} \mathrm{C}$ then allowed to gradually warm to room temperature and stirred an additional $1 \mathrm{~h}$. The reaction was quenched with saturated ammonium chloride and extracted twice with ethyl acetate. The combined organic layers were washed with brine, dried over $\mathrm{MgSO}_{4}$, filtered, and concentrated to an oily residue which was purified with flash chromatography (15-20\% ethyl acetate in hexanes) to give $667 \mathrm{mg}$ 3-(2,3-dimethylbutyryl)-2oxazolidinone (95\%); ${ }^{1} \mathrm{H} \mathrm{NMR}\left(\mathrm{CDCl}_{3}\right) \delta .0 .90(\mathrm{~d}, J=6.6,3 \mathrm{H}), 0.94(\mathrm{~d}, J=6.6,3 \mathrm{H}), 1.98(\mathrm{~m}$, $1 \mathrm{H}), 3.61(\mathrm{~m}, 1 \mathrm{H}), 4.02(\mathrm{dt}, J=8.1,2.4,2 \mathrm{H}), 4.39(\mathrm{t}, J=8.1,2 \mathrm{H}){ }^{13} \mathrm{C}$ NMR 22.9, 25.4, 42.9, $43.9,62.3,153.9,173.2$. The acylated oxazolidinone (600 mg, $2.66 \mathrm{mmol})$ was dissolved in 12

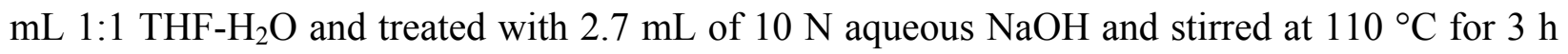
after which the reaction was cooled, diluted to $100 \mathrm{~mL}$ with $1 \mathrm{~N} \mathrm{NaOH}$, and washed two times with ethyl acetate. The aqueous layer was acidified to $\mathrm{pH}<2$ with sulfuric acid and extracted three times with ethyl acetate. The combined organic layers were washed with brine, dried over $\mathrm{MgSO}_{4}$, filtered, and concentrated give $261 \mathrm{mg}(63 \%)$ of the title compound as an oil that solidified upon standing; ${ }^{1} \mathrm{H} \mathrm{NMR}\left(\mathrm{CDCl}_{3}\right) \delta 0.93(\mathrm{~d}, J=6.3,6 \mathrm{H}), 1.12(\mathrm{~d}, J=6.6,3 \mathrm{H}), 1.88(\mathrm{~m}$, $1 \mathrm{H}), 3.44(\mathrm{~m}, 1 \mathrm{H}) ;{ }^{13} \mathrm{C} \mathrm{NMR}\left(\mathrm{CDCl}_{3}\right) \delta$ 13.3, 19.0, 20.6, 30.7, 46.0, 183.2.

$( \pm$ )-2-Cyclohexylpropionic acid. Following the procedure for the synthesis of $( \pm)-2,3$ dimethylbutanoic acid, the achiral intermediate 3-(cyclohexylaceto)-2-oxazolidone was obtained in $82 \%$ yield; ${ }^{1} \mathrm{H}$ NMR $\left(\mathrm{CDCl}_{3}\right) \delta .0 .95-1.80(\mathrm{~m}, 11 \mathrm{H}), 2.81(\mathrm{~d}, J=6.4,2 \mathrm{H}), 4.02(\mathrm{t}, J=8.0$, $2 \mathrm{H}), 4.41(\mathrm{t}, J=8.0,2 \mathrm{H})$. Methylation as above provided 3-(2-cyclohexylpropionyl)-2oxazolidinone $(95 \%) ;{ }^{1} \mathrm{H}$ NMR $\left(\mathrm{CDCl}_{3}\right) \delta .0 .80-1.80(\mathrm{~m}, 11 \mathrm{H}), 1.11(\mathrm{~d}, J=6.8,3 \mathrm{H}), 3.67(\mathrm{~m}$, $1 \mathrm{H}), 4.02(\mathrm{~m}, 2 \mathrm{H}), 4.40(\mathrm{t}, J=7.8,2 \mathrm{H})$. Finally, the free acid was obtained after hydrolysis and work-up as above in 63\% yield; ${ }^{1} \mathrm{H}$ NMR $\left(\mathrm{CDCl}_{3}\right) \delta 0.90-1.80(\mathrm{~m}, 11 \mathrm{H}), 1.13(\mathrm{~d}, J=6.9,3 \mathrm{H})$, $2.28(\mathrm{~m}, 1 \mathrm{H})$.

\section{General method for the preparation of carboxylic acid chlorides}

The appropriate carboxylic acid (1.0 equiv.) was treated with $\mathrm{KOH}$ (1.0 equiv., $2 \mathrm{~N}$ in water) and heated at $60{ }^{\circ} \mathrm{C}$ with stirring for $30 \mathrm{~min}$. Water was removed by sequential azeotropic concentrations with methanol and toluene under reduced pressure and heat followed by storage under high vacuum for 12 hours. The dried carboxylic acid salt was suspended in toluene (to 0.4 $\mathrm{M}$ ), a catalytic amount of pyridine was added and the reaction was cooled to $0{ }^{\circ} \mathrm{C}$. Oxalyl chloride ( 2 equiv.) was added dropwise to the cooled solution that was then allowed to warm to room temperature and stirred for $2 \mathrm{~h}$. The reaction was concentrated under reduced pressure to $1 / 5$ the original volume, filtered, and further concentrated to a slightly viscous liquid with some solids. The crude acid chloride was dissolved in dry THF to an approximately $2 \mathrm{M}$ concentration and used in this form for further reactions. 


\section{General methods for the formation of diastereomeric derivatives of 1}

Method A: NaHMDS (1.1 equiv., 1.0 M in THF) was added to a cooled $\left(-78^{\circ} \mathrm{C}\right)$ solution of 1 (1.0 equiv., $0.2 \mathrm{M}$ in THF). The solution was stirred $1 \mathrm{~h}$ at $-78^{\circ} \mathrm{C}$ after which the appropriate acid chloride (1.2 equiv., $2 \mathrm{M}$ in THF) was added. The reaction was allowed to gradually warm to room temperature and monitored by TLC until completion (1-2 h) after which the reaction was quenched with saturated ammonium chloride and extracted with ethyl acetate. The organic layer was washed sequentially with saturated sodium bicarbonate and brine, dried over $\mathrm{MgSO}_{4}$, filtered, and concentrated to an oil. Purification by flash chromatography using 5-20\% ethyl acetate in hexanes provided yields between $82-95 \%$.

Method B: Dicyclohexylcarbodiimide (DCC, 1.2 equiv., $2 \mathrm{M}$ in DCM) was added to a cooled solution $\left(0^{\circ} \mathrm{C}\right)$ of 1 (1.0 equiv.), 4-( $N, N^{\prime}$-dimethylamino)pyridine (DMAP, 0.1 equiv.) and the appropriate carboxylic acid (1.1 equiv.) in DCM (to $0.2 \mathrm{M}$ in 1). The reaction was allowed to gradually warm to room temperature and stirred for $12 \mathrm{~h}$. The resultant mixture was filtered to remove the urea by-product and concentrated to an oily solid. Purification by flash chromatography (10-30\% ethyl acetate in hexanes) provided isolated yields between $45-85 \%$.

Method C: The appropriate prochiral carboxylic acid or acid chloride was coupled to 1 following either method A or method B to generate acylated-1. NaHMDS (1.1 equiv., 1.0 M in THF) was added to a cooled solution $\left(-78^{\circ} \mathrm{C}\right)$ of the acylated-1 $(0.2 \mathrm{M}$ in THF $)$ and stirred for 30 min. The appropriate alkyl iodide ( 2 equiv.) was added and the reaction was brought to room temperature with stirring until completion (30 min-1 h). After work-up (as in method A), the diastereomeric products were isolated by flash chromatography (10-30\% ethyl acetate in hexanes) with the $2^{\prime} R$ diastereomer in excesses ranging from 10:1 to $3: 1$ over the $2^{\prime} S$ diastereomer as determined by ${ }^{1} \mathrm{H}$ NMR.

(2R)-2-tert-Butyl-1-carbomethoxy-3-[(R)-2-phenylpropionyl]-2,3-dihydro-4(1H)-

pyrimidinone (1A). Following Method A; ${ }^{1} \mathrm{H}$ NMR (acetone- $\left.d_{6}\right) \delta 0.95(\mathrm{~s}, 9 \mathrm{H}), 1.45(\mathrm{~d}, J=7.2$, $3 \mathrm{H}), 3.83(\mathrm{~s}, 3 \mathrm{H}), 5.00(\mathrm{q}, J=6.9,1 \mathrm{H}), 5.12(\mathrm{~d}, J=8.0,1 \mathrm{H}), 6.71(\mathrm{~d}, J=1.6,1 \mathrm{H}), 7.12-7.26$ (aromatic, $5 \mathrm{H}), 7.58(\mathrm{dd}, J=7.6,1.2,1 \mathrm{H}) ;{ }^{13} \mathrm{C}$ NMR (acetone- $\left.d_{6}\right) \delta 20.5,27.3,40.4,45.9,54.8$, 70.7, 104.9, 127.6, 128.6, 129.1, 140.5, 141.9, 153.1, 164.7, 176.0.

(2R)-2-tert-Butyl-1-carbomethoxy-3-[(S)-2-phenylpropionyl]-2,3-dihydro-4(1H)-

pyrimidinone (1B). Following Method A; ${ }^{1} \mathrm{H}$ NMR (acetone- $\left.d_{6}\right) \delta 0.79(\mathrm{~s}, 9 \mathrm{H}), 1.38(\mathrm{~d}, J=6.8$, $3 \mathrm{H}), 3.88(\mathrm{~s}, 3 \mathrm{H}), 4.81(\mathrm{q}, J=6.9,1 \mathrm{H}), 5.33(\mathrm{~d}, J=7.6,1 \mathrm{H}), 6.93(\mathrm{~d}, J=1.2,1 \mathrm{H}), 7.19-7.46$ (aromatic, $5 \mathrm{H}), 7.76(\mathrm{dd}, J=8.0,1.2,1 \mathrm{H}) ;{ }^{13} \mathrm{C}$ NMR (acetone- $\left.d_{6}\right) \delta 21.2,27.2,41.3,46.4,54.8$, 69.6, 105.3, 127.5, 129.1, 129.2, 140.6, 142.8, 153.3, 164.1, 175.5 .

(2R)-2-tert-Butyl-1-carbomethoxy-3-[(R)-2-phenylbutyryl]-2,3-dihydro-4(1H)-pyrimidinone (4A). Following Method A; ${ }^{1} \mathrm{H}$ NMR $\delta$ (acetone- $\left.d_{6}\right)$ ) $0.88(\mathrm{t}, J=7.2,3 \mathrm{H}), 0.96(\mathrm{~s}, 9 \mathrm{H}), 1.72(\mathrm{~m}$, $J=5.6,1 \mathrm{H}), 2.16(\mathrm{~m}, J=5.6,1 \mathrm{H}), 3.80(\mathrm{~s}, 3 \mathrm{H}), 4.86(\mathrm{t}, J=7.2,1 \mathrm{H}), 5.15(\mathrm{~d}, J=7.6,1 \mathrm{H}), 6.74$ $(\mathrm{d}, J=1.2,1 \mathrm{H}), 7.13-7.35$ (aromatic, $5 \mathrm{H}), 7.58(\mathrm{dd}, J=7.8,1.0,1 \mathrm{H}) ;{ }^{13} \mathrm{C}$ NMR (acetone- $\left.d_{6}\right) \delta$ $12.8,27.3,28.4,40.8,53.1,54.8,70.5,104.9,127.7,129.2,129.6,140.1,140.5,153.2,164.7$, 175.3 . 
(2R)-2-tert-Butyl-1-carbomethoxy-3-[(S)-2-phenylbutyryl]-2,3-dihydro-4(1H)-pyrimidinone (4B). Following Method A; ${ }^{1} \mathrm{H}$ NMR $\delta$ (acetone- $\left.d_{6}\right) 0.75(\mathrm{t}, J=7.2,3 \mathrm{H}), 0.79(\mathrm{~s}, 9 \mathrm{H}), 1.76(\mathrm{~m}, J$ $=5.7,1 \mathrm{H}), 2.03(\mathrm{~m}, J=5.6,1 \mathrm{H}), 3.88(\mathrm{~s}, 3 \mathrm{H}), 4.58(\mathrm{t}, J=7.4,1 \mathrm{H}), 5.35(\mathrm{~d}, J=8.0,1 \mathrm{H}), 6.92(\mathrm{~d}$, $J=1.2,1 \mathrm{H}), 7.19-7.48$ (aromatic, $5 \mathrm{H}), 7.78(\mathrm{dd}, J=7.8,1.4,1 \mathrm{H}) ;{ }^{13} \mathrm{C}$ NMR (acetone- $\left.d_{6}\right) \delta 12.7$, 27.2, 29.5, 41.3, 53.8, 54.8, 69.6, 105.3, 127.4, 128.0, 128.8, 140.6, 141.3, 154.6, 164.2, 175.2.

(2R)-2-tert-Butyl-1-carbomethoxy-3-[(R)-3-methyl-2-phenylbutyryl]-2,3-dihydro-4(1H)pyrimidinone (5A). Following Method A; ${ }^{1} \mathrm{H}$ NMR $\delta$ (acetone- $\left.d_{6}\right) 0.65(\mathrm{~d}, J=6.8,1 \mathrm{H}), 0.96(\mathrm{~s}$, 9H), $1.09(\mathrm{~d}, J=6.4,1 \mathrm{H}), 2.46(\mathrm{~m}, J=6.6,1 \mathrm{H}), 3.78(\mathrm{~s}, 3 \mathrm{H}), 4.74(\mathrm{~d}, J=10.0,1 \mathrm{H}), 5.19(\mathrm{~d}, J=$ $8.0,1 \mathrm{H}), 6.72(\mathrm{~d}, J=1.2,1 \mathrm{H}), 7.14-7.33$ (aromatic, 5H), $7.57(\mathrm{dd}, J=7.6,1.2,1 \mathrm{H}) ;{ }^{13} \mathrm{C}$ NMR (acetone- $d_{6}$ ) $\delta 20.7,22.3,27.4,32.7,40.8,54.8,58.5,70.3,104.8,127.9,129.1,129.5,139.4$, $140.6,153.0,164.9,175.1$.

(2R)-2-tert-Butyl-1-carbomethoxy-3-[(S)-3-methyl-2-phenylbutyryl]-2,3-dihydro-4(1H)pyrimidinone (5B). Following Method A; ${ }^{1} \mathrm{H}$ NMR $\delta$ (acetone- $\left.d_{6}\right) 0.63(\mathrm{~d}, J=6.8,1 \mathrm{H}), 0.77(\mathrm{~s}$, 9H), $0.88(\mathrm{~d}, J=6.4,1 \mathrm{H}), 2.41(\mathrm{~m}, J=6.6,1 \mathrm{H}), 3.88(\mathrm{~s}, 3 \mathrm{H}), 4.32(\mathrm{~d}, J=10.8,1 \mathrm{H}), 5.38(\mathrm{~d}, J=$ $8.0,1 \mathrm{H}), 6.90(\mathrm{~d}, J=1.2,1 \mathrm{H}), 7.17-7.52$ (aromatic, $5 \mathrm{H}), 7.81(\mathrm{dd}, J=7.8,1.4,1 \mathrm{H}) ;{ }^{13} \mathrm{C}$ NMR (acetone- $d_{6}$ ) $\delta 20.7,21.8,27.2,34.1,41.2,54.9,59.7,69.8,105.3,127.6,128.7,130.1,139.7$, $140.8,153.2,164.5,175.5$.

(2R)-2-tert-Butyl-1-carbomethoxy-3-[(R)-2-methoxy-2-phenylacetyl]-2,3-dihydro-4(1H)pyrimidinone (6A). Following Method A; ${ }^{1} \mathrm{H}$ NMR $\delta$ (acetone- $\left.d_{6}\right) 0.97(\mathrm{~s}, 9 \mathrm{H}), 3.38(\mathrm{~s}, 3 \mathrm{H})$, $3.81(\mathrm{~s}, 3 \mathrm{H}), 5.17(\mathrm{~d}, J=7.8,1 \mathrm{H}), 6.04(\mathrm{~s}, 1 \mathrm{H}), 6.71(\mathrm{~d}, J=1.2,1 \mathrm{H}), 7.25-7.35$ (aromatic, $5 \mathrm{H})$, $7.62(\mathrm{dd}, J=7.8,1.2,1 \mathrm{H}) ;{ }^{13} \mathrm{C}$ NMR (acetone- $\left.d_{6}\right) \delta 27.3,40.9,54.9,57.7,70.8,83.7,104.7$, $128.7,129.2,129.4,137.7,141.1,153.3,164.7,172.9$.

(2R)-2-tert-Butyl-1-carbomethoxy-3-[(S)-2-methoxy-2-phenylacetyl]-2,3-dihydro-4(1H)pyrimidinone (6B). Following Method A; ${ }^{1} \mathrm{H}$ NMR $\delta$ (acetone- $d_{6} 0.77(\mathrm{~s}, 9 \mathrm{H}), 3.22(\mathrm{~s}, 3 \mathrm{H}), 3.88$ $(\mathrm{s}, 3 \mathrm{H}), 5.38(\mathrm{~d}, J=7.8,1 \mathrm{H}), 5.78(\mathrm{~s}, 1 \mathrm{H}), 6.86(\mathrm{~d}, J=1.5,1 \mathrm{H}), 7.28-7.59$ (aromatic, 5H), 7.81 $(\mathrm{dd}, J=7.8,1.5,1 \mathrm{H}) ;{ }^{13} \mathrm{C}$ NMR (acetone- $\left.d_{6}\right) \delta 27.1,41.3,54.9,57.5,70.0,83.8,105.0,128.9$, $129.0,129.8,138.2,141.3,153.5,164.1,172.5$.

(2R)-2-tert-Butyl-1-carbomethoxy-3-[(R)-2-(1-naphthyl)propionyl]-2,3-dihydro-4(1H)pyrimidinone (7A). Following Method A; ${ }^{1} \mathrm{H}$ NMR $\delta$ (acetone- $\left.\left.d_{6}\right)\right) 0.97(\mathrm{~s}, 9 \mathrm{H}), 1.58(\mathrm{~d}, J=$ $7.2,3 \mathrm{H}), 3.84(\mathrm{~s}, 3 \mathrm{H}), 4.91(\mathrm{~d}, J=7.6,1 \mathrm{H}), 5.70(\mathrm{q}, J=6.9,1 \mathrm{H}), 6.76(\mathrm{~d}, J=1.2,1 \mathrm{H}), 7.52$ (COSY, 1H), 7.16-8.02 (aromatic, 5H); ${ }^{13} \mathrm{C}$ NMR (acetone- $d_{6}$ ) $\delta 19.5,27.3,40.9,43.0,54.8$, $71.1,104.7,123.9,124.9,126.0,126.4,126.9$, 128.2, 129.5, 132.3, 134.9, 138.8, 140.5, 153.1, 164.6, 176.7 .

(2R)-2-tert-Butyl-1-carbomethoxy-3-[(S)-2-(1-naphthyl)propionyl]-2,3-dihydro-4(1H)pyrimidinone (7B). Following Method A; ${ }^{1} \mathrm{H}$ NMR $\delta$ (acetone- $d_{6} 0.90(\mathrm{~s}, 9 \mathrm{H}), 1.48(\mathrm{~d}, J=7.2$, $3 \mathrm{H}), 3.89(\mathrm{~s}, 3 \mathrm{H}), 5.32(\mathrm{~d}, J=7.6,1 \mathrm{H}), 5.62(\mathrm{q}, J=6.8,1 \mathrm{H}), 6.96(\mathrm{~d}, J=1.2,1 \mathrm{H}), 7.80(\mathrm{COSY}$, $1 \mathrm{H}), 7.43-8.24$ (aromatic, $5 \mathrm{H}$ ); ${ }^{13} \mathrm{C}$ NMR (acetone- $\left.d_{6}\right) \delta 19.8,27.5,41.2,42.5,54.8,69.9,105.2$, $124.4,124.7,126.0,126.3,126.7,127.9,129.5,132.3,135.1,139.3,140.8,153.3,164.4,175.5$.

(2R)-2-tert-Butyl-1-carbomethoxy-3-[(R)-2-(1-pyrenyl)propionyl]-2,3-dihydro-4(1H)pyrimidinone (8A). Following Method A; ${ }^{1} \mathrm{H}$ NMR $\delta$ (acetone- $\left.d_{6}\right) 0.97(\mathrm{~s}, 9 \mathrm{H}), 1.69(\mathrm{~d}, J=6.8$, 
$3 \mathrm{H}), 3.82(\mathrm{~s}, 3 \mathrm{H}), 4.71(\mathrm{~d}, J=7.6,1 \mathrm{H}), 5.99(\mathrm{q}, J=7.1,1 \mathrm{H}), 6.81(\mathrm{~d}, J=1.2,1 \mathrm{H}), 7.35(\mathrm{~d}, J=$ 7.2, 1H), 8.04-8.31 (aromatic, 5H); ${ }^{13} \mathrm{C}$ NMR (acetone- $\left.d_{6}\right) \delta 20.2,27.3,40.9,43.6,54.9,71.4$, $104.7,123.9,125.6,125.8,125.9,126.0,126.0,126.3,127.2,128.2,128.4,128.7,129.5,131.3$, $131.9,132.4,136.8,140.7,153.4,164.8,177.3$.

(2R)-2-tert-Butyl-1-carbomethoxy-3-[(S)-2-(1-pyrenyl)propionyl]-2,3-dihydro-4(1H)pyrimidinone (8B). Following Method A; ${ }^{1} \mathrm{H}$ NMR $\delta$ (acetone- $\left.d_{6}\right) 0.88(\mathrm{~s}, 9 \mathrm{H}), 1.62(\mathrm{~d}, J=6.9$, $3 \mathrm{H}), 3.90(\mathrm{~s}, 3 \mathrm{H}), 5.32(\mathrm{~d}, J=7.8,1 \mathrm{H}), 5.92(\mathrm{q}, J=7.0,1 \mathrm{H}), 7.03(\mathrm{~d}, J=1.2,1 \mathrm{H}), 7.80(\mathrm{~d}, J=$ 8.0, 1H), 8.04-8.54 (aromatic, 5H); ${ }^{13} \mathrm{C}$ NMR (acetone- $d_{6}$ ) $\delta 20.8,27.4,41.3,43.2,54.9,70.0$, $105.4,124.8,125.3,125.8,125.8,125.9,126.1,126.1,127.1,128.0,128.3,128.5,129.5,131.2$, $132.0,132.5,137.6,141.0,153.6,164.6,176.0$.

(2R)-2-tert-Butyl-1-carbomethoxy-3-[(R)-3-methyl-2-(1-naphthyl)butyryl]-2,3-dihydro4(1H)-pyrimidinone (9A). Following Method A; ${ }^{1} \mathrm{H}$ NMR $\delta$ (acetone- $d_{6} 0.63(\mathrm{~d}, J=6.8,1 \mathrm{H})$, $0.97(\mathrm{~s}, 9 \mathrm{H}), 1.23(\mathrm{~d}, J=6.4,1 \mathrm{H}), 2.60(\mathrm{~m}, J=6.6,1 \mathrm{H}), 3.72(\mathrm{~s}, 3 \mathrm{H}), 4.98(\mathrm{~d}, J=8.0,1 \mathrm{H}), 5.62$ $(\mathrm{d}, J=10.0,1 \mathrm{H}), 6.67(\mathrm{~s}, 1 \mathrm{H}), 7.40(\mathrm{COSY}, 1 \mathrm{H}), 7.39-8.14$ (aromatic, $5 \mathrm{H}) ;{ }^{13} \mathrm{C} \mathrm{NMR}\left(\mathrm{CDCl}_{3}\right) \delta$ $20.3,22.0,26.9,33.5,40.0,52.9,54.2,70.2,104.2,123.0,124.6,125.3,125.5,126.2,127.5$, $128.8,131.3,133.9,137.6,139.2,152.2,164.7,175.7$.

(2R)-2-tert-Butyl-1-carbomethoxy-3-[(S)-3-methyl-2-(1-naphthyl)butyryl]-2,3-dihydro4(1H)-pyrimidinone (9B). Following Method A; ${ }^{1} \mathrm{H}$ NMR $\delta$ (acetone- $\left.d_{6}\right) 0.62(\mathrm{~d}, J=6.8,1 \mathrm{H})$, $0.76(\mathrm{~s}, 9 \mathrm{H}), 1.01(\mathrm{~d}, J=6.4,1 \mathrm{H}), 2.50(\mathrm{~m}, J=6.6,1 \mathrm{H}), 3.90(\mathrm{~s}, 3 \mathrm{H}), 5.38(\mathrm{~d}, J=8.0,1 \mathrm{H}), 5.43$ $(\mathrm{d}, J=10.0,1 \mathrm{H}), 7.00(\mathrm{~d}, J=1.2,1 \mathrm{H}), 7.82(\mathrm{COSY}, 1 \mathrm{H}), 7.45-8.51$ (aromatic, $5 \mathrm{H}) ;{ }^{13} \mathrm{C}$ NMR $\left(\mathrm{CDCl}_{3}\right) \delta 20.3,21.6,26.7,35.1,40.5,54.0,54.3,69.1,105.1,123.4,123.7,125.2,125.5,126.1$, $127.4,128.9,131.2,134.1,137.8,139.2,152.6,163.8,175.1$.

(2R)-2-tert-Butyl-1-carbomethoxy-3-[(R)-2-(4-iso-butylphenyl)propionyl]-2,3-dihydro4(1H)-pyrimidinone (10A). Following Method A; ${ }^{1} \mathrm{H}$ NMR $\delta$ (acetone- $\left.d_{6}\right) 0.85(\mathrm{~d}, J=6.6$, $3 \mathrm{H}), 0.94(\mathrm{~s}, 9 \mathrm{H}), 1.43(\mathrm{~d}, J=7.2,3 \mathrm{H}), 1.88(\mathrm{~m}, J=6.6,1 \mathrm{H}), 2.41(\mathrm{~d}, J=7.5,2 \mathrm{H}), 3.82(\mathrm{~s}, 3 \mathrm{H})$, 4.95 (q, $J=7.0,1 \mathrm{H}), 5.11(\mathrm{~d}, J=7.8,1 \mathrm{H}), 6.67(\mathrm{~d}, J=1.2,1 \mathrm{H}), 7.13(\mathrm{~d}, J=8.1,2 \mathrm{H}), 7.25(\mathrm{~d}, J$ $=7.8,2 \mathrm{H}), 7.39-7.27$ (aromatic, $5 \mathrm{H}), 7.55(\mathrm{dd}, J=7.8,1.2,1 \mathrm{H}) ;{ }^{13} \mathrm{C}$ NMR (acetone- $\left.d_{6}\right) \delta 20.3$, $22.7,22.8,27.3,31.1,40.9,45.6,45.7,54.8,71.0,105.1,128.6,130.0,139.5,140.6,141.1$, $153.4,165.1,176.7$.

(2R)-2-tert-Butyl-1-carbomethoxy-3-[(S)-2-(4-iso-butylphenyl)propionyl]-2,3-dihydro4(1H)-pyrimidinone (10B). Following Method A; ${ }^{1} \mathrm{H}$ NMR $\delta$ (acetone- $\left.d_{6}\right) 0.78(\mathrm{~s}, 9 \mathrm{H}), 0.87$ (d, $J=6.6,3 \mathrm{H}), 0.88(\mathrm{~d}, J=6.6,3 \mathrm{H}), 1.38(\mathrm{~d}, J=6.9,3 \mathrm{H}), 1.90(\mathrm{~m}, J=6.8,1 \mathrm{H}), 2.45(\mathrm{~d}, J=7.2$, $2 \mathrm{H}), 3.88(\mathrm{~s}, 3 \mathrm{H}), 4.84(\mathrm{q}, J=6.9,1 \mathrm{H}), 5.33(\mathrm{~d}, J=7.8,1 \mathrm{H}), 6.93(\mathrm{~d}, J=1.2,1 \mathrm{H}), 7.11(\mathrm{~d}, J=$ $8.4,2 \mathrm{H}), 7.37(\mathrm{~d}, J=8.1,2 \mathrm{H}), 7.09-7.39$ (aromatic, 5H), $7.76(\mathrm{dd}, J=7.8,1.5,1 \mathrm{H}) ;{ }^{13} \mathrm{C}$ NMR (acetone- $d_{6}$ ) $\delta 20.9,22.7,22.8,27.2,31.1,41.3,45.7,45.9,54.8,69.6,105.6,129.1,129.8$, $140.1,140.7,140.8,153.6,164.4,176.1$.

(2R)-2-tert-Butyl-1-carbomethoxy-3-[(R)-2-(2-(6-methoxynaphthyl))propionyl]-2,3-dihydro4(1H)-pyrimidinone (11A). Following Method B; ${ }^{1} \mathrm{H}$ NMR $\delta$ (acetone- $\left.d_{6}\right) 0.94(\mathrm{~s}, 9 \mathrm{H}), 1.52$ (d, $J=7.2,3 \mathrm{H}), 3.82(\mathrm{~s}, 3 \mathrm{H}), 3.90(\mathrm{~s}, 3 \mathrm{H}), 5.06(\mathrm{q}, J=6.9,1 \mathrm{H}), 5.14(\mathrm{~d}, J=8.0,1 \mathrm{H}), 7.46(\mathrm{dd}, J=$ 8.4, 2.0, 1H), 7.09-7.84 (aromatic, 5H); ${ }^{13} \mathrm{C}$ NMR (acetone- $d_{6}$ ) $\delta ~ 20.9,26.1,39.8,45.4,54.8$, 
$55.7,68.4,105.4,119.7,126.6,127.1,127.2,127.8,129.6,129.8,131.0,134.4,139.0,140.6$, 158.0, 164.2, 176.0.

(2R)-2-tert-Butyl-1-carbomethoxy-3-[(S)-2-(6-methoxy-2-naphthyl)propionyl]-2,3-dihydro4(1H)-pyrimidinone (11B). Following Method A; ${ }^{1} \mathrm{H}$ NMR $\delta$ (acetone- $\left.d_{6}\right) 0.78(\mathrm{~s}, 9 \mathrm{H}), 1.46(\mathrm{~d}$, $J=6.8,3 \mathrm{H}), 3.88(\mathrm{~s}, 3 \mathrm{H}), 3.90(\mathrm{~s}, 3 \mathrm{H}), 4.95(\mathrm{q}, J=6.9,1 \mathrm{H}), 5.34(\mathrm{~d}, J=8.0,1 \mathrm{H}), 6.96(\mathrm{~s}, 1 \mathrm{H})$, $7.56(\mathrm{dd}, J=8.6,1.8,1 \mathrm{H}), 7.11-7.83$ (aromatic, $5 \mathrm{H}) ;{ }^{13} \mathrm{C}$ NMR (acetone- $\left.d_{6}\right) \delta 21.1,27.2,41.3$, $46.3,54.8,55.7,69.6,106.4,119.4,126.6,127.3,127.4,128.0,130.0,131.9,134.5,137.8,138.6$, 140.6, 158.4, 164.1, 175.6 .

(2R)-2-tert-Butyl-1-carbomethoxy-3-[(R)-2-methylbutyryl]-2,3-dihydro-4(1H)-pyrimidinone (12A). Following Method A; ${ }^{1} \mathrm{H}$ NMR $\delta$ (acetone- $\left.d_{6}\right) 0.77(\mathrm{t}, J=7.3,3 \mathrm{H}), 0.93(\mathrm{~s}, 9 \mathrm{H}), 1.20$ (d, $J=6.6,3 \mathrm{H}), 1.36(\mathrm{~m}, J=7.3,1 \mathrm{H}), 1.64(\mathrm{~m}, J=7.4,1 \mathrm{H}), 3.36(\mathrm{~m}, J=7.2,1 \mathrm{H}), 3.87(\mathrm{~s}, 3 \mathrm{H})$, $5.35(\mathrm{~d}, J=7.8,1 \mathrm{H}), 6.84(\mathrm{~d}, J=1.5,1 \mathrm{H}), 7.78(\mathrm{dd}, J=7.8,1.5,1 \mathrm{H}) ;{ }^{13} \mathrm{C}$ NMR (acetone- $\left.d_{6}\right) \delta$ 12.4, 18.8, 27.5, 28.1, 41.3, 42.7, 55.1, 70.1, 105.7, 141.1, 153.8, 165.1, 178.7.

(2R)-2-tert-Butyl-1-carbomethoxy-3-[(S)-2-methylbutyryl]-2,3-dihydro-4(1H)-pyrimidinone (12B). Following Method A; ${ }^{1} \mathrm{H}$ NMR $\delta$ (acetone- $\left.d_{6}\right) 0.95(\mathrm{t}, J=7.3,3 \mathrm{H}), 0.93(\mathrm{~s}, 9 \mathrm{H}), 1.01$ (d, $J$ $=6.6,3 \mathrm{H}), 1.41(\mathrm{~m}, J=7.3,1 \mathrm{H}), 1.89(\mathrm{~m}, J=6.8,1 \mathrm{H}), 3.43(\mathrm{~m}, J=7.0,1 \mathrm{H}), 3.87(\mathrm{~s}, 3 \mathrm{H}), 5.33$ $(\mathrm{d}, J=7.8,1 \mathrm{H}), 6.88(\mathrm{~d}, J=1.2,1 \mathrm{H}), 7.77(\mathrm{dd}, J=7.8,1.5,1 \mathrm{H}) ;{ }^{13} \mathrm{C}$ NMR (acetone- $\left.d_{6}\right) \delta 12.3$, $17.1,27.5,28.6,41.3,42.1,55.1,69.9,105.7,141.0,153.8,165.0,178.4$.

(2R)-2-tert-Butyl-1-carbomethoxy-3-[(R)-2,3-dimethylbutyryl]-2,3-dihydro-4(1H)-

pyrimidinone (13A). Following Method B from 1 and ( \pm )-2,3-dimethylbutanoic acid for larger amounts, and Method $\mathrm{C}$ for assignment of stereochemistry; ${ }^{1} \mathrm{H}$ NMR (acetone- $\left.d_{6}\right) \delta 0.77(\mathrm{~d}, J=$ $6.6,3 \mathrm{H}), 0.84(\mathrm{~d}, J=6.9,3 \mathrm{H}), 0.94(\mathrm{~s}, 9 \mathrm{H}), 1.16(\mathrm{~d}, J=6.9,3 \mathrm{H}), 1.84(\mathrm{~m}, J=7.0,1 \mathrm{H}), 3.25(\mathrm{~m}$, $J=7.1,1 \mathrm{H}), 3.87(\mathrm{~s}, 3 \mathrm{H}), 5.36(\mathrm{~d}, J=7.8,1 \mathrm{H}), 6.79(\mathrm{~d}, J=0.9,1 \mathrm{H}), 7.80(\mathrm{dd}, J=7.8,1.2,1 \mathrm{H})$; ${ }^{13} \mathrm{C}$ NMR (acetone- $d_{6}$ ) $\delta 15.7,19.4,21.6,27.3,32.3,41.1,47.0,54.9,70.1,105.4,141.0,153.5$, $165.2,178.5$.

(2R)-2-tert-Butyl-1-carbomethoxy-3-[(S)-2,3-dimethylbutyryl]-2,3-dihydro-4(1H)-

pyrimidinone (13B). Following Method B from 1 and $( \pm)$-2,3-dimethylbutanoic acid for larger amounts, and Method $\mathrm{C}$ for assignment of stereochemistry; ${ }^{1} \mathrm{H}$ NMR $\delta$ (acetone- $\left.d_{6}\right) 0.87(\mathrm{~d}, J=$ $6.9,3 \mathrm{H}), 0.95(\mathrm{~d}, J=6.9,3 \mathrm{H}), 0.94(\mathrm{~s}, 9 \mathrm{H}), 1.00(\mathrm{~d}, J=6.6,3 \mathrm{H}), 2.18(\mathrm{~m}, J=6.5,1 \mathrm{H}), 3.39(\mathrm{~m}$, $J=5.2,1 \mathrm{H}), 3.86(\mathrm{~s}, 3 \mathrm{H}), 5.33(\mathrm{~d}, J=8.1,1 \mathrm{H}), 6.90(\mathrm{~s}, 1 \mathrm{H}), 7.76(\mathrm{dd}, J=8.0,1.0,1 \mathrm{H}) ;{ }^{13} \mathrm{C}$ NMR (acetone- $\left.d_{6}\right) \delta 13.1,17.9,21.8,27.3,31.3,41.0,45.9,54.9,69.5,110.6,140.8,153.5$, 164.9, 177.7 .

(2R)-2-tert-Butyl-1-carbomethoxy-3-[(R)-2-cyclohexylpropionyl]-2,3-dihydro-4(1H)pyrimidinone (14A). Following Method B from 1 and ( \pm )-2,3-dimethylbutanoic acid for larger amounts, and Method $\mathrm{C}$ for assignment of stereochemistry; ${ }^{1} \mathrm{H}$ NMR $\delta$ (acetone- $d_{6}$ ) $0.80-1.85$ (cyclohexyl, 11H), 0.94 (s, 9H), 1.15 (d, $J=6.4,3 \mathrm{H}), 3.28$ (q, $J=5.1,1 \mathrm{H}), 3.87$ (s, 3H), 5.36 (d, $J=8.0,1 \mathrm{H}), 6.78(\mathrm{~d}, J=1.2,1 \mathrm{H}), 7.80(\mathrm{dd}, J=7.6,1.2,1 \mathrm{H}) ;{ }^{13} \mathrm{C}$ NMR (acetone- $\left.d_{6}\right) \delta 15.7$, 27.0, 27.1, 27.2, 27.2, 30.3, 32.2, 40.9, 42.0, 45.9, 54.8, 69.9, 105.3, 140.7, 153.1, 164.9, 178.1.

(2S)-2-tert-Butyl-1-carbomethoxy-3-[(R)-2-cyclohexylpropionyl]-2,3-dihydro-4(1H)pyrimidinone (14B). Following Method B from 1 and ( \pm )-2,3-dimethylbutanoic acid for larger 
amounts, and Method $\mathrm{C}$ for assignment of stereochemistry; ${ }^{1} \mathrm{H}$ NMR $\delta$ (acetone- $\left.d_{6}\right) 0.92-1.85$ (cyclohexyl, 11H), $0.94(\mathrm{~s}, 9 \mathrm{H}), 0.96(\mathrm{~d}, J=7.2,3 \mathrm{H}), 3.41$ (q, $J=4.1,1 \mathrm{H}), 3.86(\mathrm{~s}, 3 \mathrm{H}), 5.33$ (d, $J=7.6,1 \mathrm{H}), 6.89(\mathrm{~d}, J=1.2,1 \mathrm{H}), 7.76(\mathrm{dd}, J=7.8,1.4,1 \mathrm{H}) ;{ }^{13} \mathrm{C}$ NMR (acetone- $\left.d_{6}\right) \delta 13.9$, 27.3, 27.3, 27.3, 27.5, 28.9, 32.5, 40.8, 41.5, 45.2, 54.7, 69.4, 105.4, 140.4, 153.1, 164.5, 177.2 .

\section{Acknowledgements}

This work was supported by grants from The Welch Foundation (\#96-086) and NIGMS (S06 GM08194). We thank Mr. Jesus A. Garcia and Ms. Michelle M. McShane Kawasaki for technical support. RSM was partially supported by a departmental grant from The Welch Foundation.

\section{References and Notes}

1. Current address: Millennium Pharmaceuticals, Inc., 75 Sidney St., Cambridge, MA 02139.

2. Current address: Texas Biotechnology Corporation, 7000 Fannin, 20th Floor, Houston, TX 77030.

3. Peng, J.; Odom, J. D.; Dunlap, R. B.; Silks, L. A. III Tetrahedron: Asymmetry 1994, 5, 1627.

4. Tyrrell, E.; Tsang, M. W. H.; Skinner, G. A.; Fawcett, J. Tetrahedron 1996, 52, 9841.

5. Ichikawa, A.; Hiradate, S.; Sugio, A.; Kuwahara, S.; Watanabe, M.; Harada, N. Tetrahedron: Asymmetry 1999, 10, 4075.

6. Yabuuchi, T.; Kusumi, T. J. Org. Chem. 2000, 65, 397.

7. Ferreiro, M.J.; Latypov, S.K.; Quiñoá, E.; Riguera, R. J. Org. Chem. 2000, 65, 2658.

8. Trost, B. M.; Bunt, R. C.; Pulley, S. R. J. Org. Chem.1994, 59, 4202.

9. Dale, J. A.; Mosher, H. S. J. Am. Chem. Soc. 1973, 95, 512.

10. Sullivan, G. R.; Dale, J. A.; Mosher, H. S. J. Org. Chem. 1973, 38, 2143.

11. Trost, B. M.; Belletire, J. L.; Godleski, S.; McDougal, P. G.; Balkovc, J. M. J. Org. Chem. 1986, 51, 2370.

12. Seco, J. M.; Quiñoá, E.; Riguera, R. J. Org. Chem. 1999, 64, 4669.

13. Kouda, K.; Kusumi, T.; Ping, X.; Kan, Y.; Hashimoto, T.; Asakawa, Y. Tetrahedron Lett. 1996, 37, 4541.

14. Latypov, S. K.; Ferreiro, M. J.; Quiñoá, E.; Riguera, R. J. Am. Chem. Soc. 1998, 120, 4741.

15. Chu, K. S.; Negrete, G. R.; Konopelski, J. P.; Lakner, F. J.; Woo, N.-T.; Olmstead, M. M. J. Am. Chem. Soc. 1992, 114, 1800.

16. Boyd, V. A.; Perales, J. B.; Negrete, G. R. Tetrahedron Lett. 1997, 38, 6631.

17. Procedure: DCC ( 0.1 equiv) was added in one portion to a cooled solution $\left(0^{\circ} \mathrm{C}\right)$ of 1 (1 equiv), carboxylic acid (1.1 equiv) and DMAP (1.2 equiv) in $\mathrm{CH}_{2} \mathrm{Cl}_{2}$. The reaction was 
allowed to gradually warm to room temperature and stirred for $12 \mathrm{~h}$. The resultant mixture was filtered to remove the urea by-product and concentrated to an oily solid. Purification by flash chromatography provided isolated yields between 64-85\%. All compounds were analyzed by ${ }^{1} \mathrm{H}$ - and ${ }^{13} \mathrm{C}-\mathrm{NMR}$.

18. Seyden-Penne, J. Chiral Auxiliaries and Ligands in Asymmetric Synthesis; J. Wiley \& Sons: New York, NY, 1995; pp 172-187.

19. Piccolo, O.; Menicagli, R.; Lardicci, L. Tetrahedron 1979, 35, 1751.

20. Matsumoto, T.; Ishida, T.; Takeda, Y.; Soh, K.; Kubo, I.; Sakamoto, M. Chem. Pharm. Bull. 1995, 43, 216.

21. Ogura, K.; Mitamura, S.; Kishi, K.; Tsuchihashi, G.-I Synthesis 1979, 880.

22. Newman, P. Optical Resolution Procedures for Chemical Compounds Vol. 1., Acids, part 1, Optical Resolution Information Center, Riverdale, NY, 1981, p. 552.

23. Tamura, Y.; Yakura, T.; Shirouchi, Y.; Haruta, J.-I. Chem. Pharm. Bull. 1985, 33, 1097. 